Bangladesh J. Bot. 49(3): 611-617, 2020 (September)

\title{
GENETICS OF LODGING RESISTANCE RELATED TRAITS IN BREAD WHEAT (TRITICUM AESTIVUM L.)
}

\author{
Sana Muazzam*, Abdus Salam Khan, Zulfiqar Ali ${ }^{1}$ \\ and Sultan Habibullah KhaN ${ }^{2}$ \\ Department of Plant Breeding and Genetics, University of Agriculture, \\ Faisalabad, Pakistan
}

Keywords: Gene action, Genetic variability, Additives, Epistasis, Segregations

\begin{abstract}
To evaluate the genetic background of lodging traits, six populations of two wheat crosses were sown under different nitrogen levels by using split plot design. Generation mean analysis was used to estimate the gene action for lodging related traits. Results showed genetic variability and significant differences for all traits. Allelic and non-allelic gene actions were operative for different traits with different magnitude under both normal and lodging condition. Duplicate types of espistasis were observed for grain yield per plant, 1000- kernel weight, number of grains per spike and number of tillers. The stem diameter, height of basal nodes and basal inter-nodal distance depicted the additive, additive $\times$ dominance and dominance gene action. The aforementioned results showed that plant height, stem diameter, height of basal nodes and basal internodal distance were more prone traits for lodging and selection should be practiced in later generations with increasing homozygosity.
\end{abstract}

\section{Introduction}

Wheat (Triticum aestivum L.) is one of the important agricultural crops as well as staple food in the world. In Pakistan, wheat occupies a pivotal position and dominates all other crops in acreage and production, accounts for approximately $9.9 \%$ of value added and $2 \%$ of GDP in agriculture sector (Anon. 2016). Getting higher yield in both irrigated and water scare environments has been restricted by lodging, about 20 - 40\% reduction in final grain weight has been witnessed due to lodging (Stapper and Fischer 1990, Berry et al. 2004). Lodging affects the crop net yield by altering the plant standing condition, preventing proper light and air, restricting the assimilation of dry matter and nutrients, respiration and providing favorable conditions for pathogen proliferation (Berry and Spink 2012).

The interaction among the factors like plants, rainfall pattern, wind speed and soil quality, nitrogen fertilizer and inefficient management practices together cause the lodging. To understand the nature and mechanism of lodging in field, nitrogen $(\mathrm{N})$ regulation is the best method for screening and identifying the lodging resistance genotypes as it mainly affects the plant anchor related traits like plant height, number of internodes, length of internodes, stem thickness, stem weight, anatomical ratio of second internode diameter $(\mathrm{mm})$ to stem length (cm) (Zuber et al. 1999, Berry et al. 2004). The study was initiated to investigate the genetic architecture of lodging resistance traits, their gene actions and lodging resistance in two selected crosses. It could be useful to identify the potential for further breeding programs by identifying parental lines with high rate of desirable segregates.

*Author for correspondence: <sanamuazzam@ymail.com>. ${ }^{1}$ Muhammad Nawaz Sharif University of Agriculture, Multan, Pakistan. ${ }^{2}$ Center of Agriculture Biotechnology and Biology, University of Agriculture, Faisalabad, Pakistan. 


\section{Materials and Methods}

The experimental material was planted at the research field of the Department of Plant Breeding and Genetics (PB\&G), University of Agriculture, Faisalabad, Pakistan during 2012 2016. The experiment material consisted of four parents' genotypes named as Aas-2011, Chenab2000, Saher-2006 and Bhakkar-2001 and their subsequent generations viz., first filial generation $\left(F_{1}\right)$, segregating generation $\left(F_{2}\right)$, first backcross $\left(B_{1}\right)$ generation and second backcross $\left(\mathrm{BC}_{2}\right)$ generation. Two lodging resistance varieties (Chenab-2000 and Bhakkar-2001) and two lodging susceptible varieties (Aas-2011 and Saher-2006) were selected upon screening and crosses (Aas$2011 \times$ Chenab-2000 and Saher-2006 × Bhakkar-2001) were made between parents in $2012-2103$ cropping season.

The $F_{1}$ seeds and their parental seeds were harvested separately at maturity. In $2013-14$ cropping season, $F_{1}$ were sown along with parents to produce backcrosses by crossing the $F_{1}$ with their respective recurrent parents. The seeds from all generations with two replicates were sown in the field by using split plot design under two doses of nitrogen fertilizer application named as normal N (nitrogen @ $120 \mathrm{~kg} / \mathrm{ha}$ ) and lodging L (nitrogen @ $240 \mathrm{~kg} / \mathrm{ha}$ ) in 2014 - 2015 growing season.

Periodically normal agronomic practices were carried out throughout the experiment, random selection of ten plants from each replication were done and tagged. Data were recorded for traits such as plant height $(\mathrm{cm})$, spike length $(\mathrm{cm})$, peduncle length $(\mathrm{cm})$, number of tillers, stem diameter $(\mathrm{mm})$, number of nodes per stem, height of basal node $(\mathrm{cm})$, basal internodes distance $(\mathrm{cm})$, number of grains/spike, 1000-kernel weight $(\mathrm{g})$ and grain yield/plant $(\mathrm{g})$ with respect to growth stages especially critical stages for lodging (heading, anthesis and maturity). The averages of individual plant were analyzed using ANOVA (Steel et al. 1997). The generation mean analysis given by Mather and Jinks (1982) was followed to study the gene action for each trait.

\section{Results and Discussion}

ANOVA revealed significant differences for all factors such as genotypes, treatments and their interaction and also revealed significant statistical differences under both nitrogen level for all the parameters expect number of nodes per stem (Tables 1 and 2). Morphological traits that correlate with lodging can be used as a selection parameter that gives an indirect estimation to assess the lodging resistance (Berry et al. 2003). The traits under study were significantly affected by the double nitrogen $(240 \mathrm{~kg} / \mathrm{ha}$ ) levels (lodging field condition), these results were in accordance with many researchers lines as increase in nitrogen rate increased tillering, plant height, length of basal internodes and decreased the stem diameter and first node length which ultimately increase the chances of crop lodging (Pinthus 1974, Wei et al. 2008).

The additive-dominance model of generation mean analysis was followed for analyzing the differences between generations and all tests shown significance at 5\% level of confidence. The both wheat crosses were evaluated under normal $(\mathrm{N})$ and lodging $(\mathrm{L})$ field conditions. The results obtained by generation mean analysis are presented in Tables 3 and 4. Under both environments, different model parameters were operated for different traits.

Under normal condition, in cross-I the additive (md) gene action was observed for plant height, spike length, peduncle length, stem diameter, while height of basal node and basal internodes distance exhibited additive $\times$ additive and additive $\times$ dominance gene actions, respectively. Number of tillers/plant, number of grain/spike, 1000-kernel weight and grain yield/plant showed presence of duplicate type of epistasis. In lodging condition traits of cross-I such as stem diameter, height of basal nodes and basal internodes distance showed additive gene 


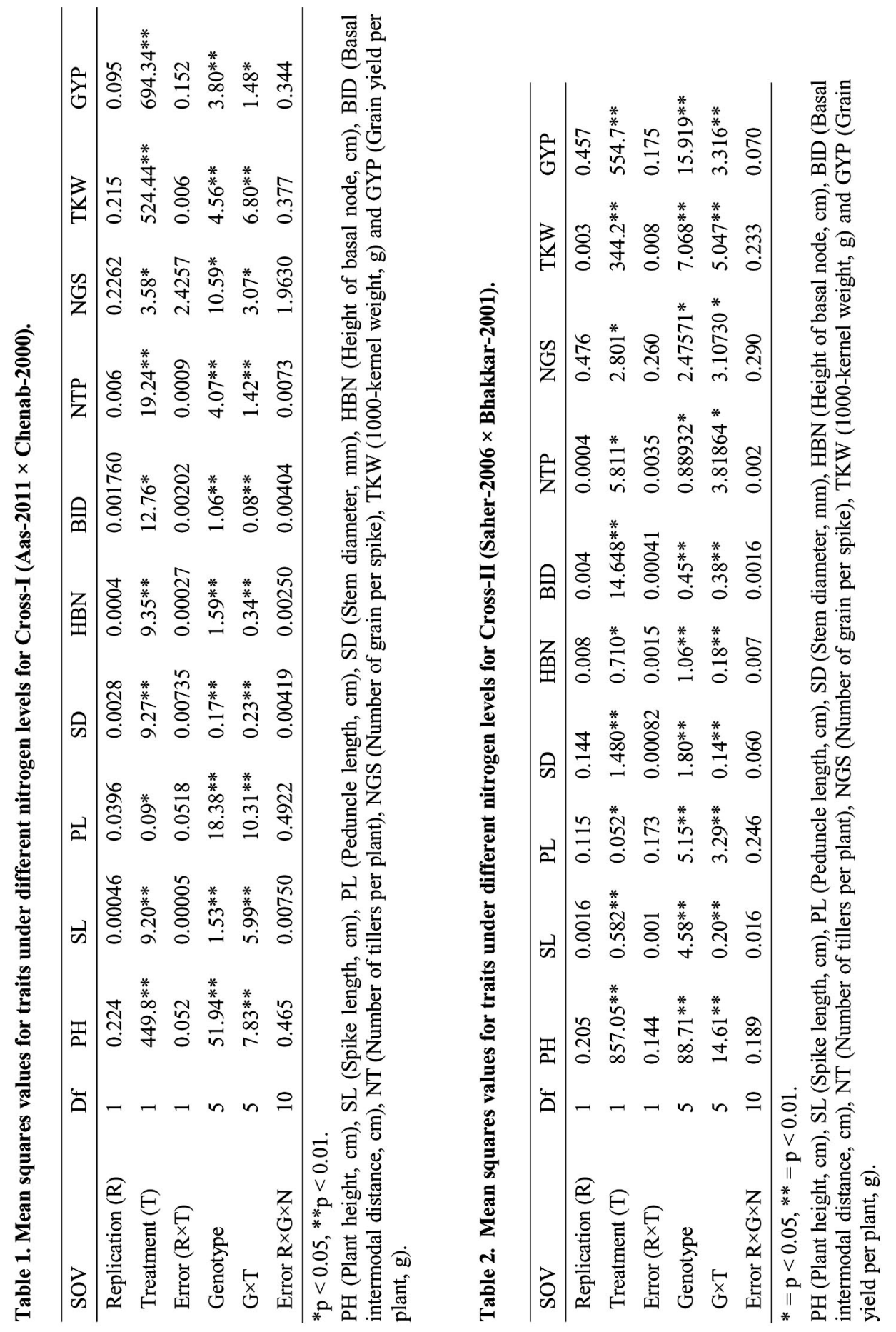




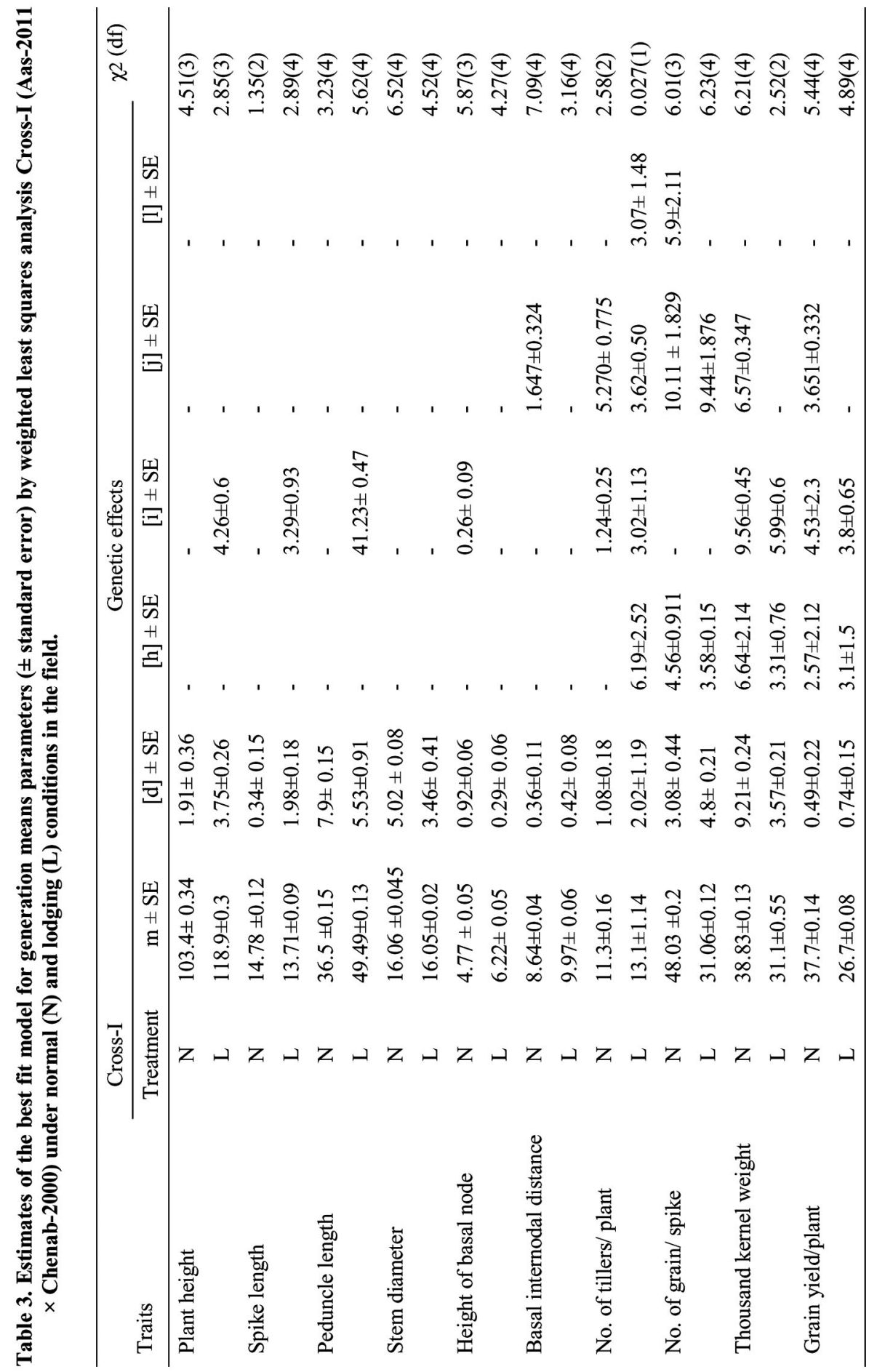




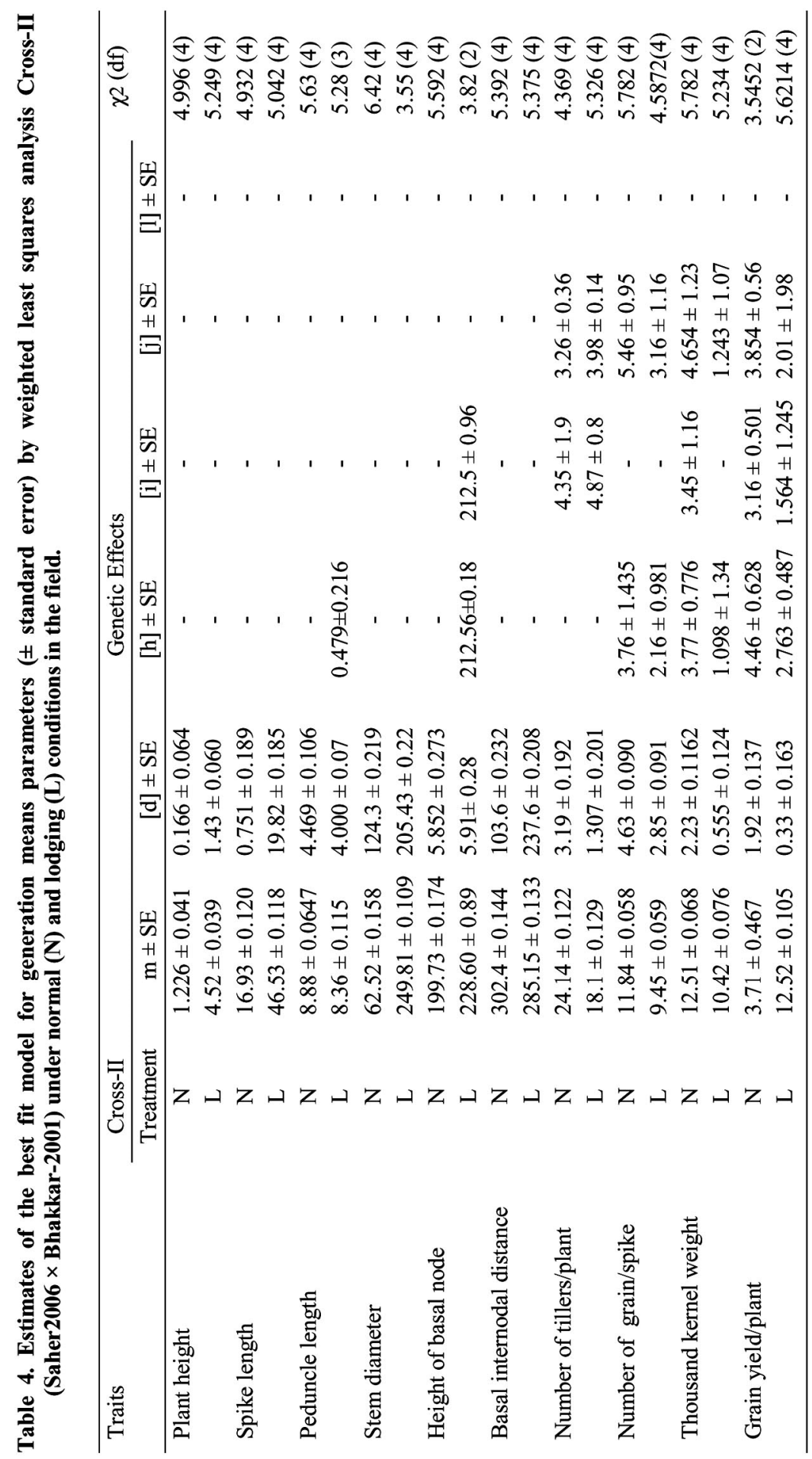


action, whereas additive $\times$ additive gene action was observed for plant height, spike length and peduncle length. Double epistasis exhibited by grain yield/plant, 1000-kernel weight, number of grain/spike and number of tillers/plant (Table 3).

Similarly, the cross-II showed additive nature of gene action for plant height, spike length, peduncle length, stem diameter and basal internodes distance under both lodging and no lodging condition except height of basal node that showed additive in normal condition while epistasis effects in lodging condition. Double epistasis effects persisted under both conditions with different magnitude for number of tillers per plant, number of grains per spike, 1000-kernel weight and grain yield per plant (Table 4).

These aforementioned results indicated that gene actions (additive, dominance and epistastic effects) operated differently for traits under studay and showed the different levels of significane but magnitude changed with each cross. Stem morpohological traits like basal internodal distance was under epistatic interaction (Zuber et al. 1999, Berry et al. 2000). Pinthus (1974), Islam et al. (2007) reported that plant height and stem morphological traits were closely related to lodging resistance and by increasing the stem diameter the lodging resistance can be improved in crops (Kong et al. 2013, Peng et al. 2014). Herein, plant height, stem diameter, and average stem wall thickness were controlled by additive gene effects. Dominance $\times$ dominance interaction effect was the most active component on non-allelic effects and observed significant for most of the traits (basal inter-nodal distance, number of tillers per plant, number of grains per spike, 1000-kernel weight and grain yield per plant). Magnitude of dominance $\times$ dominance gene action exerted greater influnced than additive $\times$ dominance gene action upon most of the traits in both crosses under both field conditions. These collaborated with the findings of Misra et al. (1994), Sarker et al. (2007).

From the present study it may be concluded that the traits exhibited additive gene action would be more responsive as compared to the dominance and other non-allelic genetic effects. Increasing nitrogen fertilizer increases the risk of lodging significantly. Selection in early segregating generations restrict the expression and would not be effective for the flexible components of variation. The present findings are considered valuable for enhancing lodging resistance of wheat and improving grain yield and quality.

\section{References}

Anonymous 2016. Government of Pakistan. Statistical supplement, Economic Survey. Ministry of Finance Division, Economic Advisor's Wing, Islamabad, Pakistan. 28-29 pp.

Berry PM, Griffin JM, Sylvester-Bradley R, Scott RK, Spink JH and Baker CJ 2000. Controlling plant form through husbandry to minimize lodging in wheat. Field Crops Res. 67: 59-81.

Berry PM and Spink J 2012. Predicting yield losses caused by lodging in wheat. Field Crops Res. 137: 19-26.

Berry PM, Sterling M, Baker CJ, Spink J, and Sparkes DL 2003. A calibrated model of wheat lodging compared with field measurements. Agric. For. Meteorol. 1193: 167-180.

Berry PM, Sterling M, Spink JH, Baker CJ, Bradley RS, Mooney S, Tams A and Ennos AR 2004. Understanding and reducing lodging in cereals. Adv. Agron. 84: 215-269.

Islam MS, Peng S, Visperas RM, Ereful N, Bhuiya MSU and Julfiquar AW 2007. Lodging-related morphological traits of hybrid rice in a tropical irrigated ecosystem. Field Crops Res. 101: 240-248.

Kong E, Liu D, Guo X, Yang W, Sun J, Li X, Zhan K, Cui D, Lin J and Zhang A 2013. Anatomical and chemical characteristics associated with lodging resistance in wheat. Crop J. 1: 43-49.

Mather K and Jinks L $\left(3^{\text {rd }}\right)$ 1982. Biometrical genetics, the study of continuous variation. Chapman and Hall, London, Newyork. 403 pp.

Misra SC, Rao VS, Dixit RN, Surve VD and Patil VP 1994. Genetic control of yield and its components in bread wheat. Indian J. Genet. 54: 77-82. 
Peng D, Chen X, Yin Y, Lu K, Yang W, Tang Y and Wang Z 2014. Lodging resistance of winter wheat (Triticum aestivum L.): Lignin accumulation and its related enzymes activities due to the application of paclobutrazol or gibberellin acid. Field Crops Res. 157: 1-7.

Pinthus M J 1974. Lodging in wheat, barley, and oats: The phenomenon, its causes, and preventive measures. Adv. Agron. 25: 209-263.

Sarker ZI, Shamsuddin AKM, Rahman L and Ara R 2007. Gene actions of traits contributing to lodging resistance in wheat (Triticum aestivum L). Bangladesh J. Pl. Breed. Genet. 20: 23-30.

Stapper M, and Fischer RA 1990. Genotype, sowing date and plant spacing influence on high-yielding irrigated wheat in Southern New South Wales. Potential yields and optimum flowering dates. Aust. J. Agric. Res. 41: 1043-1056.

Steel RGD, Torrie JH and Dickey DA (3rd) 1997. Principles and Procedures of Statistics: A Biometrical Approach, McGrwa Hill Book Co., New York, USA. 352-358 pp.

Wei FZ, Li JC, Wang CY, Qu HJ and Shen XS 2008. Effects of nitrogenous fertilizer application model on culm lodging resistance in winter wheat. Acta Agronomica Sinica 6: 026.

Zuber U, Winzeler H, Messmer MM, Keller B, Schmid JE and Stamp P 1999. Morphological traits associated with lodging resistance of spring wheat (Triticum aestivum L.). J. Agron. Crop Sci. 182: $17-24$.

(Manuscript received on 10 March, 2019; revised on 9 December, 2019) 